\title{
Türkiye'de ve bazı ülkelerde baklagiller üretimindeki işgücü verimliliğinin karşılaştırılması
}

\section{Ergün ŞIMSȘEK ${ }^{1}$}

${ }^{1}$ Amasya Üniversitesi Sosyal Bilimler Meslek Yüksekokulu, Amasya

Alınış tarihi: 8 Ağustos 2018, Kabul tarihi: 20 Kasım 2018

Sorumlu yazar: Ergün ŞİMŞEK, e-posta: ergun.simsek@amasya.edu.tr

\section{Öz}

Bu çalışmada amaç 1991-2016 döneminde üretim miktarı yüksek olan beş ülke ve Türkiye'de baklagillerde işgücü verimliliğini karşılaştırmalı olarak incelemektir. Bu amaçla, öncelikle ülkelerin baklagiller üretim miktarı ve ekim alanlarındaki yıllık ortalama değişim trendi belirlenmiștir. Trendin belirlenmesinde 1980-2016 dönemi ele alınmış ve 1980 yılı temel yıl olarak kabul edilmiştir. Yıllık ortalama değişim oranının belirlenmesinde logaritmik regresyon denklemi kullanılmıştır. İşgücü verimliliğinin hesaplanmasında 1991 yılının temel olarak alındığı endeksleme oran analiz yöntemi kullanılmıștır. Elde edilen sonuçlara göre Türkiye'de baklagiller üretim miktarı ve ekim alanlarında 1980'li yılların sonu ve 1990'lı yılların başlarında büyük artışlar meydana gelmiștir. Ancak daha sonraki yıllarda üreticilerin baklagiller üretiminden çekildiği ve ekim alanlarının azaldığı görülmüştür. 1991-2016 döneminde kuru fasulyede işgücü verimliliği Türkiye'de 1'den 1.83'e çıkmıştır. Dünya ortalaması da 1.68 olmuştur. Aynı yıllarda Mercimekte işgücü verimliliği Türkiye'de 1'den 0.94 'e düşerken dünya ortalaması 2.68'e çıkmıştır. Nohut üretiminde işgücü verimliliği Türkiye'de 1'den 0.88 'e düşerken, dünya ortalaması 1.68 'e çıkmıștır. Dolayısıyla Türkiye baklagiller yönünden kendi kendine yeterliliğini büyük ölçüde kaybetmiş ve net ithalatçı ülke konumuna gelmiştir. $\mathrm{Bu}$ nedenle Türkiye'deki baklagiller üreticilerinin, üretime yönelmesini sağlayacak politikaların uygulamaya konulması gerekmektedir.

Anahtar kelimeler: Baklagiller, işgücü verimliliği, baklagiller ekim alanı, baklagiller üretim
A comparison of labor productıvity in the production of legumes in Turkey and in some countries

\begin{abstract}
This study aims 1991-2016 period, labor productivity in the production of high amounts of legumes in five countries and Turkey is to analyze comparatively. For this purpose, firstly the annual average change trend of the amount of legumes produced and the cultivation areas of the countries were determined. The 1980-2016 period was dealt with in the determination of the trend and 1980 was considered as the base year. The logarithmic regression equation was used to determine the annual mean change rate The calculation of labor productivity is based on the year 1991 and the index ratio analysis method is used. According to the results obtained in the amount of legumes production and acreage in Turkey the end of the 1980s and in the early 1990s, large increases occurred. However, in the following years it was seen that the producers were pulled out of the legumes production and the planting area decreased. Dry beans in the 1991-2016 period, labor productivity increased to 1.83 to 1 in Turkey. The world average was 1.68 . Lentils in labor productivity in the same year decreased to 0.94 to 1 in Turkey, but the world has increased to an average of 2.68 to 1. Chickpeas in labor productivity decreased to 0.88 to 1 in Turkey, the world average rose to 1.68 from 1. Thus, Turkey has lost its self-sufficiency in terms of legumes substantially and has become a net importer country. Therefore legumes producers in Turkey, it is necessary to ensure the implementation of policies towards production.
\end{abstract}


Key words: Legumes, labor productivity, legume planting area, legume production

\section{Giriş}

Tarım sektörü diğer sektörlerde olduğu gibi tüm dünyada büyük değişim ve dönüşüm yaşamaktadır. Sosyal ve ekonomik alanda meydana gelen gelişmeler yanında, meydana gelen krizler, dengeli beslenme ve gıda güvenliğinin ön plana geçmesi, iklim koşullarında meydana gelen değişimler ve hatta insanların tüketim kalıplarında meydana gelen değişimler bu değişim ve dönüşümü tetiklemektedir. Bütün bu olgular tarım sektörünün önemini artırmaktadır denilebilir. $\mathrm{Bu}$ gelişmeler doğrultusunda, tarım sektöründe, beklenen yapısal dönüşümü sağlayacak, küresel iklim değişikliği ve olası krizlerin etkilerini engelleyecek veya azaltacak, ayrıca uluslararası taahhütlere uyumu kolaylaştıracak tarımsal politikalara yön verecek iyi bir planlamanın yapilması zorunludur (KB, 2014). Çünkü bir yandan artan nüfusa bağlı olarak ortaya çıkan tarımsal ürün talebindeki artış, diğer yandan tarımsal ürünlerin dünyanın her tarafına eşit dağılımını engelleyen koşullar bir çok ülkede dengesiz beslenmeye ve hatta açlığa neden olmaktadır. Bu önemli sorunların üstesinden gelmek için tarımsal üretimin ve özellikle de tarımda bitkisel üretimin arttırılması bir zorunluluk olarak karşımıza çlkmakta olup bu nedenle hemen bütün ülkelerde tarım sektörü çeșitli șekillerde desteklenmektedir.
2016 yılı itibarı ile OECD ülkelerinde tarımsal üreticilere verilen destek tutarı 235 milyar dolar olmuştur (OECD, 2018). Aynı yılda Türkiye'deki üretici destekleri 16,5 milyar dolar olmuştur.

Çalışmanın konusunu oluşturan baklagiller insan yaşamında pek çok etkiye sahiptir. Ekonomik olarak sağladıkları katkı yanında insanların beslenmesinde ve hatta bitkisel üretim de ekim nöbeti yönünden de önemli katkıları mevcuttur. İnsanların beslenmesi açısından yüksek oranda protein içeren baklagiller aynı zamanda bu proteinlerin hazmedilebilme derecelerinin de yüksek olması nedeniyle önem arz etmektedir. Diğer yandan içerdikleri mutlak gerekli aminoasitler yönünden hayvansal proteinlere yakın olmaları nedeniyle özellikle gelişmekte olan ülkelerde düşük proteinli ve yüksek enerjili besinlerin eksikliklerini giderici olarak büyük ölçüde kullanılmaktadırlar (Çiftçi, 2004). Dünyada insan beslenmesinde, bitkisel proteinlerin \%22'sinin, karbonhidratların \%7'sinin, hayvan beslenmesindeki proteinlerin \%38'inin, karbonhidratların \%5'inin yemeklik baklagillerce sağlandığı (Wery and Gricnac, 1983) düşünüldüğünde bu gruptaki ürünlerin üretiminin arttırılmasının ne denli önemli olduğu ortaya çıkmaktadır. Bitkisel üretimde önemli bir payı olan baklagiller içerisinde gerek üretim ve gerekse ekim alanı olarak en büyük paya sahip olan mercimek, fasulye ve nohut'un dünyada ve Türkiye'de 1991-2016 yıllarındaki karşılaştırılması Çizelge 1'de verilmiştir.

Çizelge 1. Türkiye'de ve Dünya'da baklagiller üretim ve ekim alanlarındaki değișim (1991-2016)

\begin{tabular}{|c|c|c|c|c|c|}
\hline \multirow{2}{*}{ Ülke } & \multirow{2}{*}{ Ürünler } & \multicolumn{2}{|c|}{1991} & \multicolumn{2}{|c|}{2016} \\
\hline & & Üretim miktarı (Ton) & Ekim alanı (ha) & Üretim miktarı (Ton) & Ekim alanı (ha) \\
\hline \multirow{3}{*}{ Dünya } & K. Fasulye & 18015992 & 25505767 & 26833394 & 29392817 \\
\hline & Mercimek & 2658011 & 3268804 & 6315858 & 5481120 \\
\hline & Nohut & 8119373 & 11438152 & 12092950 & 12650078 \\
\hline \multicolumn{2}{|c|}{ Toplam } & 28793376 & 40212723 & 45242202 & 47524015 \\
\hline \multirow{3}{*}{ Türkiye } & K. Fasulye & 214000 & 177676 & 235000 & 88548 \\
\hline & Mercimek & 640000 & 787449 & 365000 & 246322 \\
\hline & Nohut & 855000 & 874393 & 455000 & 351687 \\
\hline \multicolumn{2}{|c|}{ Toplam } & 1709000 & 1839518 & 1055000 & 686557 \\
\hline
\end{tabular}

Kaynak: FAO (2018a). Crops Productions, http://www.fao.org/faostat

TÜİK, 2018a. Bitkisel Üretim İstatistikleri, http://www.tuik.gov.tr/PreTablo.

Çizelge'de görüleceği üzere çalışmada ele alınan kuru fasulye, mercimek ve nohut itibarı ile dünyada toplam olarak 1991 yılında 40212723 ha alan da 28793376 ton üretilirken, 2016 yılında 47524015 ha alanda 45242202 ton üretim gerçekleştirilmiştir. Dolayısıyla dönem içerisinde gerek ekim alanlarında ve gerekse üretim miktarında artış meydana gelmiştir. Ürünler ayrı ayrı ele alındığında da bütün ürünlerde gerek ekim alanının ve gerekse üretimin arttığı görülmektedir. Türkiye'de 1991 yılı verilerine göre toplam olarak 1839518 ha alanda 1709000 ton baklagil üretimi gerçekleştirilir iken, 2016 yılında 686557 ha alanda 1055000 ton baklagil üretimi yapılmıştır. Türkiye'de dünyadaki eğilimin aksine gerek baklagiller üretim alanlarında ve gerekse üretiminde azalıșlar söz konusu olmuștur. Azalışın 
özellikle mercimek ve nohutta yoğun bir şekilde görüldüğü ve dolayısıyla üreticilerin bu alanlardan çekildiği ortaya çıkmıştır. Türkiye'de özellikle 1990’lı yılların ortasına kadar, nadas alanlarının azaltılması amacıyla uygulanan bazı politikaların sonucu olarak baklagiller ekim alanları ve dolayısıyla da üretiminde önemli artışlar sağlanmıştır. Diğer yandan Toprak Mahsulleri Ofisi (TMO) aracılığı ile nohut ve kırmızı mercimek alımı yapılması sonucunda baklagiller pazarlama sıkıntısı yaşamamıştır. 1994 yılında ülkenin yaşadığı ekonomik sıkıntılar nedeniyle, devlet bütçesine yük getirmesi gerekçesiyle TMO alımdan vazgeçmiş ve Nadas Alanlarının Daraltılması (NAD) projesi tamamlanmıştır. Bu dönemden sonra ekim alanlarında genişleme yaşanmamıș, ve hatta daralma yaşanmış olup üretimde düşüşler söz konusu olmuştur (Bolat, Ünüvar ve Dellal, 2017). TMO'nun baklagillerde destekleme alımına başlaması durumunda, mercimek ve nohut tarımımızın eski günlerine döneceği hatta daha da ileriye gideceği yadsınamaz bir gerçektir (Çiftçi, 2004). İnsan beslenmesinde önemli bir yeri olmasına rağmen baklagiller ekiliş ve üretimde istenilen seviyeye Türkiye'nin ulaşamadığı ve hatta gerilediği söylenebilir. Bu nedenle sorunun kaynağının ne olduğunun üreticilerin baklagiller üretiminden neden çekildiğinin veya üretimin neden azaldığının araştırılması gerekmektedir. Bu çalışmanın amacı, dünyanın baklagiller bakımından başat olan ülkeleri ve Türkiye'de baklagiller üretiminde kısmi işgücü verimliliğinin karşılaștırılması ve kişi başına baklagiller üretiminin yıllar itibarı ile nasıl bir değişiklik gösterdiğini ortaya koyabilmektir. Böylece Türkiye'nin gelecekte baklagiller bakımından kendi kendine yeterliliğini sağlayabilecek üretimde teknik etkinliğin sağlanması, teknolojinin iyileştirilmesi, çiftçinin ilgili alana yönlendirilmesi için çiftçi eğitim ve yayım çalışmalarının başlatılması gibi bir takım önlemler alınmak suretiyle mukayeseli üstünlüğümüzün bu alanda sürdürülmesi sağlanabilecektir.

\section{Materyal ve Yöntem}

$\mathrm{Bu}$ çalışmada kullanılan baklagiller üretim ve ekim alanları ile ilgili veriler TÜİK, ve FAO veri tabanlarından (FAO 2018a, TÜİK, 2018a, TÜİK, 2012) nüfus ile ilgili veriler TÜİK, FAO ve Worldbank veri tabanlarından (Worldbank 2018a, FAO 2018b, TÜİK 2018b, TÜİK 2012), tarımsal istihdam istatistikleri, TÜIK, FAO, ILO veri tabanlarından (TÜİK 2012, FAO 2018c, ILO 2018), alınmıştır.
Baklagiller olarak kuru baklagiller (Nohut, Mercimek ve Kuru Fasulye) ele alınmıştır. Türkiye'nin baklagiller üretiminde nasıl bir seyir izlediğini ve bu konuda dünyada başat konumda olan ülkelerle karşılaştırılması yapılırken konu biraz daha uzun vadeli olarak ele alınmış ve 1980-2016 periyodu ele alınmıştır. İşgücü verimliliğinin karşılaștırılmasında ise ele alınan periyot 1991-2016 yllarını kapsamıştır. Karşılaştırma kapsamına dahil edilen ülkeler ve ürünleri Çizelge 2'de verilmiştir.

Çizelge 2. Baklagiller üretiminde karşılaştırma yapılan ülkeler

\begin{tabular}{ccc}
\hline Kuru Fasulye & Nohut & Mercimek \\
\hline Myanmar & Hindistan & Kanada \\
Hindistan & Avustralya & Hindistan \\
Brezilya & Myanmar & ABD \\
ABD & Pakistan & Nepal \\
Tanzanya & Etiyopya & Avustralya \\
\hline
\end{tabular}

Baklagiller ekim alanları ve üretim miktarlarındaki yıllık ortalama değişimin belirlenmesinde doğrusal ve üstel trend denklemleri uygulanmıştır. Ancak bir yandan en anlamlı sonucu vermesi $\left(\mathrm{R}^{2}\right)$, diğer yandan çalışmada mutlak değişimden çok nispi değişimin daha önemli olması nedeniyle üstel trend denklemi kullanılmıştır. $\mathrm{Bu}$ amaçla gerek üretim miktarı ve gerekse ekim alanlarının önce on tabanına göre logaritmaları alınarak veriler analiz edilmiş ve daha sonra anti logaritmaları alınmıştır. Üstel trend denkleminin oluşturulmasında kullanılan formül;

$\mathrm{Y}=\alpha \cdot \beta^{\mathrm{t}}$

Burada;

$Y=$ Baklagiller Üretim ve Ekiliş alanını, $\alpha=$ Sabit katsayıyı, $\mathrm{t}=$ Zamanı (Yıl olarak), $\beta=$ Yıllık ortalama değişimi göstermektedir.

Akal, Z., (2000) yapmış olduğu bir çalışmada verimlilik göstergelerinden birisini de toplam çıktının ya da bir bölüm çıktının, ayrı ayrı her bir girdi türüne oranlanması ile elde edilen kısmi Verimlilik Oranı olarak ifade etmektedir. Bu oranlar, bir girdi cinsinin birim miktarına düşen üretim miktarını gösterir. $\mathrm{Bu}$ amaçla kullanılan formül de aşağıdaki şekilde olmuştur (Akal, 2005).

İşgücü Verimlilik Oranı $=\frac{\text { Üretim miktarı }}{\text { Adam-Saat }}$

Benzer Şekilde Ramsay (2008), verimliliği, "üretilen mal ve hizmet miktarı ile bu mal ve hizmet miktarının üretilmesinde kullanılan girdiler arasındaki oran" olarak tanımlamakta ve bu ölçüyü , çıktı/girdi olarak formüle etmektedir (Ramsay, 2008). Suiçmez, (2016), yapmış olduğu çalışmada oran analiz yöntemi kullanmış olup yıllık üretim 
değerini çalışan sayısına bölmek suretiyle işgücü verimliliğini bulmuştu (Suiçmez, 2016). Çalışmada, Baklagiller üretiminde işgücü verimliliğinin hesaplanmasında oran analiz yöntemi kullanılmıștır. $\mathrm{Bu}$ amaçla öncelikle 199991-2016 döneminde 1991=100 alınmak suretiyle baklagiller ayrı ayrı ve tarımda istihdam değerleri endekslenmiş ve bu endeksler aşağıdaki formül kullanılarak baklagiller üretiminde işgücü verimliliğine dönüştürülmüştür. Aynı dönemde dünyadaki başat konumda olan ülkeler ile Türkiye'nin karşılaștırılması yapılmıştır. .

İşücü verimliliği $=\frac{\text { Baklagiller Üretim Endeksi }}{\text { Tarımda } \text { İstihdam Edilenlerin Endeksi }}$

\section{Bulgular}

\section{Kuru fasulye ekiliş alanlarındaki değişim}

1980 yılında dünyada 25.5 milyon ha alanda 13.7 milyon ton kuru fasulye üretimi yapılırken, 2016 yılında 29.4 milyon hektar alanda 26.8 milyon ton kuru fasulye üretimi yapılmıştır. (FAO, 2018). 36 yıllık süreç içerisinde kuru fasulye üretiminde yıllık ortalama 1.72 oranında artış meydana gelirken, ekim alanlarındaki artış \%0.4 oranında olmuştur. Dönem başı ve dönem sonu dikkate alındığında ise kuru fasulye üretimi \%95 oranında artarken, ekiliş alanı sadece \%15 oranında artış göstermiştir (Çizelge 3).

Dünya kuru fasulye üretimi içerisinde 2016 yll itibarı ile en büyük paya sahip olan beş ülke sırasıyla Myanmar (\%19), Hindistan (\%14), Brezilya (\%9.7), ABD (\%4.7) ve Tanzanya (\%4.3) dır. Bu beş ülke dünya fasulye üretiminin $\% 50$ 'sinden fazlasını gerçekleştirmektedir (FAO, 2018a, TÜİK, 2018a). Türkiye kuru fasulye üretiminde 1980-2004 yılları arasında \%1-1.4' arasında bir paya sahip iken özellikle 2004 yılından sonra kuru fasulye üretiminde dünyadaki payı azalarak 2016 yılında \% 0.8 'lik payla 22. sırada yer almaktadır (FAO, 2018a, TÜİK, 2018a). Kuru fasulye üretiminde yıllık ortalama artış hızı en yüksek olan ülke \%10.09 ile
Myanmar olur iken, artış hızı en düşük olan ülke \%0.13 ile ABD olmuştur. Türkiye'de kuru fasulye üretimi yılda ortalama olarak $\% 0.54$ oranında artmakta olup dönem başı ve dönem sonu itibarı ile \%42 oranında artış gerçekleşmiştir. Bu sonuçlar göstermektedir ki, Türkiye'de kuru fasulye de yıllık ortalama artış oranı dünya ortalamasından daha düşük gerçekleşmektedir. Dünya kuru fasulye ekiliş alanları yılda ortalama olarak \%0.40 oranında artış göstermiştir. Kuru fasulye üretiminde ilk beş içerisinde yer alan ülkelerden ekiliş alanındaki yıllık ortalama artışı en yüksek olan ülke Myanmar (\%7.6) olup Tanzanya (\%3.18) ikinci sırada yer almaktadır. Hindistan'da ekiliş alanlarında bir sabitlik söz konusu olup, diğer ülkelerde ise azalışlar gerçekleşmiștir. Türkiye'de de 1980-2016 döneminde kuru fasulye ekiliş alanları yılda ortalama olarak \%1.14 oranında azalıș göstermiștir. 1980 yılı temel alındığında 2016 yılında kuru fasulye ekiliş alanı \%21.64 oranında azalmıştır. Türkiye'de kuru fasulye üretimi ve kuru fasulye ekiliş alanı birlikte değerlendirildiğinde özellikle 1980-2004 yılları arasında trendin artış yönünde olduğu ve 2004 yılında maksimum değerlere ulaştıkları görülmektedir. 2004 yılından sonra her ikisinde bir düşüşün yaşandığı ve 2008 yılından sonra ekiliş alanının azalmasına rağmen üretimin arttığı ve bunun tamamen verim artışından kaynaklandığı söylenebilir (Şekil 1). 2013 yılından sonra gerek üretim alanında ve gerekse üretimde artış olmasına rağmen bu artışlar 2000'li yılların başındaki seviyeye henüz ulaşamamıștır. TÜİK'in verilerine göre Türkiye kuru fasulyede kendine yeterli bir ülke olmayıp bu alanda net bir ithalatçı konumundadır.

2000 yılında kuru fasulyedeki yeterlilik oranı \%95 iken bu oran yükselerek 2003 yılında \%113'lere çıktıktan sonra düşmeye başlamış ve 2016 yılı itibarı ile \%81.8 olarak gerçekleşmiştir (TÜİK, 2018c).

Çizelge 3. Kuru fasulye üretim ve ekiliş alanlarındaki değişim (1980-2016)

\begin{tabular}{|c|c|c|c|c|c|c|}
\hline \multirow[b]{2}{*}{ Ülkeler } & \multicolumn{3}{|c|}{ Kuru Fasulye Üretimi } & \multicolumn{3}{|c|}{ Kuru Fasulye Ekiliș Alanı } \\
\hline & Regresyon denklemi & $\begin{array}{c}\text { Yıllık } \\
\text { ortalama } \\
\text { değişim } \\
(\%)\end{array}$ & $\begin{array}{c}\text { Endeks } \\
2016 \\
(1980=100)\end{array}$ & Regresyon denklemi & $\begin{array}{c}\text { Yıllık } \\
\text { ortalama } \\
\text { değişim }(\%)\end{array}$ & $\begin{array}{c}\text { Endeks } 2016 \\
(1980=100)\end{array}$ \\
\hline Dünya & $Y=13620242.1 .0170^{t}$ & 1.72 & 195.70 & $\mathrm{Y}=24863771.1 .0039^{t}$ & 0.40 & 115.24 \\
\hline Türkiye & $\mathrm{Y}=182209.1 .0054^{\mathrm{t}}$ & 0.54 & 142.42 & $\mathrm{Y}=167673.0 .9885^{\mathrm{t}}$ & -1.14 & 78.36 \\
\hline Myanmar & $Y=166584.1 .1009 t$ & 10.09 & 1888.85 & $Y=287215.1 .0759^{t}$ & 7.60 & 784.31 \\
\hline Hindistan & $Y=3062111.1 .0047^{t}$ & 0.48 & 141.65 & $Y=8668980.1 .0001^{t}$ & 0.02 & 101.81 \\
\hline Brezilya & $Y=2222476.1 .0110^{t}$ & 1.10 & 132.91 & $Y=5799252.0 .9829 t$ & -1.70 & 55.65 \\
\hline $\mathrm{ABD}$ & $Y=1104969.1 .0013^{t}$ & 0.13 & 104.74 & $Y=692674 \cdot 0.9964^{t}$ & -0.35 & 83.84 \\
\hline Tanzanya & $Y=205506.1 .0456^{t}$ & 4.56 & 463.21 & $Y=354113.1 .03186^{t}$ & 3.18 & 223.68 \\
\hline
\end{tabular}

Kaynak: TÜİK 2012, TÜİK 2018a ve FAO 2018a'dan alınan veriler ile tarafımızca hesaplanmıștır. 


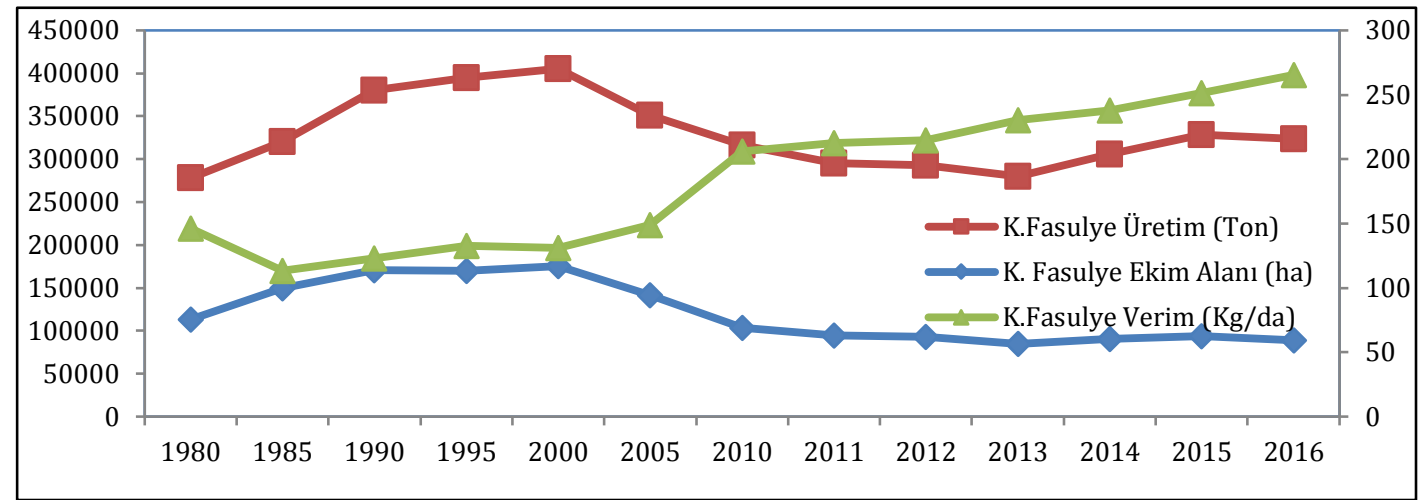

Şekil 1. Türkiye'de kuru fasulye üretim, ekim alanı ve verimdeki değişim

Türkiye'de bir yandan kuru fasulyede kendimize yeterliliği kaybederken, diğer yandan kuru fasulye ekiliş alanlarının azalması ve üreticinin kuru fasulyeden çekilmesini iyi analiz etmek gerekmektedir. Verimlilik artışı bunu bir miktar telafi etmesine rağmen kuru fasulyede net bir ithalatçı ülke olmaktan çıkmasına yetmemektedir.

\section{Nohut üretim ve ekiliş alanlarındaki değişim}

Dünyada 1980 yılında 9.63 milyon ha alanda 4.48 milyon ton nohut üretimi gerçekleștirilirken, 2016 yllında 12.65 milyon ha alanda 12.09 milyon ton nohut üretilmiștir (FAO, 2018a). 1980-2016 yılları arasında geçen 36 yıllık süreçte dünya nohut üretim miktarı yıllık ortalama \%2 civarında artış göstermiş olup, 1980 yllına nazaran 2016 yılındaki artış \%149.11 olarak gerçekleşmiştir. Aynı dönemde nohut ekiliş alanında yıllık ortalama $\% 0,73$ oranında artış ve 1980 yllına nazaran 2016 yılındaki artış da \%31,35 oranında olmuştur (Çizelge 4). Ekiliş alanındaki artışa nazaran üretim miktarındaki artışı daha fazla olması üretimdeki verim artışlarından kaynaklanmaktadır denilebilir. 2016 yllında dünya nohut üretiminin \%88.22 sine sahip olan ülkeler sırası ile Hindistan (\%64.57), Avustralya (\%7.23), Myanmar (\%4.62), Pakistan (4.27), Türkiye (\%3.76) ve Etiyopya (\%3.67) olmuştur (FAO, 2018a). Hindistan'da nohut üretimi ylllı ortalama 1.86 oranında artış göstermiş olup dönem başına nazaran dönem sonundaki artış ise \%132.96 olmuştur. Hindistan'daki nohut ekiliş alanında yıllık ortalama artış üretimde olduğu gibi dünya ortalamasının altında gerçekleşmiş (\%0.56) ve 1980 yılına nazaran 2016 yılındaki artış oranı da \%20.15 olmuştur. Avustralya'da nohut üretimindeki yıllık ortalama artış tüm ülkeler içerisinde en fazla olup \%13.01 olmuş ve dönem başına nazaran dönem sonu artışı da \%24194.25 olmuştur. Avustralya'da nohut ekim alanları da yılda ortalama \%12.76 oranında artarak başlangıç yılına nazaran 2016 yılındaki artış \%21753.03 olmuştur. Nohut üretiminde üçüncü sırada olan Myanmar da ylllık ortalama artış oranı \%5.66 olup 1980 yılına nazaran 2016 yılındaki artış oranı da \%1369.95 olmuştur. Pakistan'da nohut üretimi yılda ortalama olarak $\% 0.71$ oranında artarken, ekiliș alanındaki artıș \%0.15 olmuştur. Etiyopya'da nohut üretimindeki yıllık ortalama artış oranı \%4.77 ve ekim alanındaki artış da \%1,87 olarak gerçekleşmiştir. Türkiye'de 1980-2016 döneminde nohut üretimi yılda ortalama olarak \%0.56 oranında artış gösterirken, nohut ekim alanındaki artış ise \%0.07 oranında olmuştur. 1980 yılı temel alındığında 2016 yllında üretimdeki artış \%65.45 ve ekim alanındaki artış da \%46.53 olmuştur. Türkiye bu oranlarla dünya nohut üretiminde ilk 6 sırada bulunan ülkeler içerisinde nohut üretimindeki artış ve nohut ekim alanlarındaki artış itibarı ile dünya ortalamasının altında ve en son sırasında gelmektedir. Türkiye'nin nohut üretimi açısından kendi kendine yeterliliği incelendiğinde TÜIK'in verilerine göre 2000 yllında $\% 115.7$ olan yeterlilik 2010 yılında \%101.7 olmuş ve bu yıldan sonra yeterlilik kaybedilerek 2016 yılında yeterlilik oranı \%92.1'e düşmüştür. Şekil 2 incelendiğinde 1990 lı yıllarda başlayan nohut ekim alanlarındaki azalışın getirmiş olduğu üretim azalması son yıllardaki verim artışları ile de telafi edilmediğinden Türkiye nohut üretiminde de kendine yeterlilik durumunu muhafaza edememiş ve net ithalatçı konuma geçmiştir.

\section{Kırmızı mercimek üretim miktarı, ekim alanları ve verimdeki değişim}

Dünya'da 1980 yılı itibarı ile 21.2 milyon ha alanda 12.4 milyon ton mercimek üretilmiş olup 2016 yılında bu değerler 54.8 milyon ha ekiliş alanı ve 63.1 milyon ton mercimek üretimi olarak gerçekleşmiştir (FAO, 2018a). 
Çizelge 4. Nohut üretim ve ekiliş alanlarındaki değişim (1980-2016)

\begin{tabular}{|c|c|c|c|c|c|c|}
\hline \multirow[b]{2}{*}{ Ülkeler } & \multicolumn{3}{|c|}{ Nohut Üretimi } & \multicolumn{3}{|c|}{ Nohut Ekiliş Alanı } \\
\hline & Regresyon denklemi & $\begin{array}{c}\text { Yillık } \\
\text { ortalama } \\
\text { değișim(\%) }\end{array}$ & $\begin{array}{c}\text { Endeks } 2016 \\
(1980=100)\end{array}$ & Regresyon denklemi & $\begin{array}{c}\text { Yıllık } \\
\text { ortalama } \\
\text { değişim }(\%)\end{array}$ & $\begin{array}{c}\text { Endeks } 2016 \\
(1980=100)\end{array}$ \\
\hline Dünya & $Y=5639012.1 .0199 t$ & 2.00 & 249.11 & $Y=9360025.1 .0072^{t}$ & 0.73 & 131.35 \\
\hline Türkiye & $\mathrm{Y}=487381 \cdot 1.0055^{\mathrm{t}}$ & 0.56 & 165.45 & $Y=514437 \cdot 1.0007^{t}$ & 0.07 & 146.53 \\
\hline Hindistan & $Y=3923377 \cdot 1.0180^{t}$ & 1.86 & 232.96 & $Y=6455338 \cdot 1.0056^{t}$ & 0.56 & 120.15 \\
\hline Avustralya & $Y=12351.1 .1301^{t}$ & 13.01 & 24294.25 & $Y=12607.1 .1276^{t}$ & 12.76 & 21853.03 \\
\hline Myanmar & $Y=62306 \cdot 1.0566^{t}$ & 5.66 & 1469.95 & $Y=104601 \cdot 1.0320^{t}$ & 3.20 & 518.37 \\
\hline Pakistan & $\mathrm{Y}=441290.1 .0070^{\mathrm{t}}$ & 0.71 & 165.00 & $Y=978773 \cdot 1.0015^{t}$ & 0.15 & 89.02 \\
\hline Etiyopya & $\mathrm{Y}=67277.1 .04769^{\mathrm{t}}$ & 4.77 & 294.07 & $Y=118288 \cdot 1.0187^{t}$ & 1.87 & 138.61 \\
\hline
\end{tabular}

Kaynak: TÜİK 2012, TÜİK 2018a ve FAO 2018a'dan alınan veriler ile tarafımızca hesaplanmıștır.

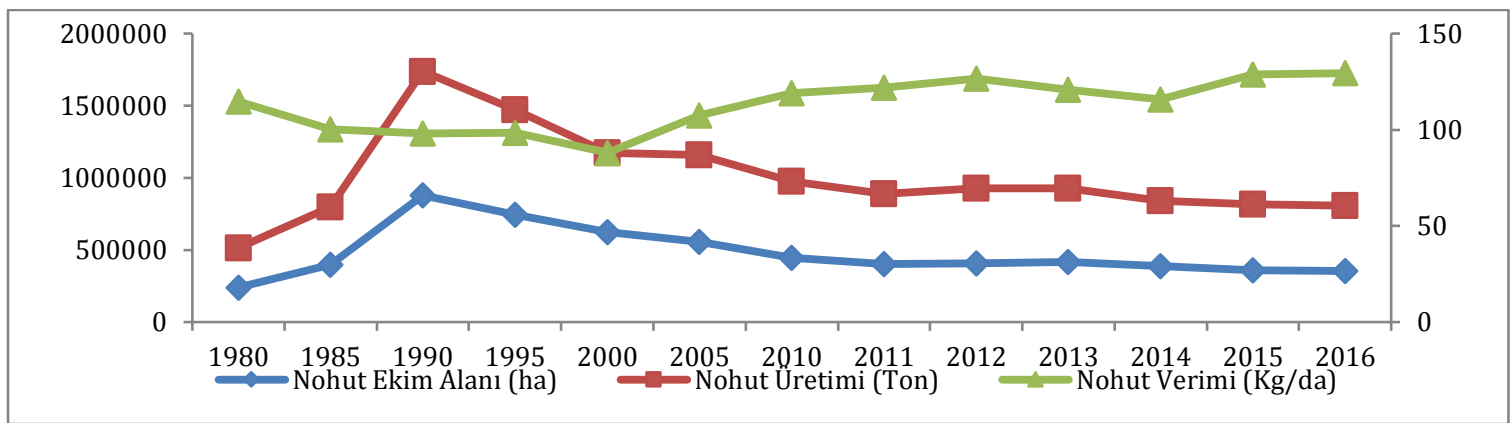

Şekil 2. Türkiye'de nohut üretim, ekiliş alanı ve verimdeki değişim

Dünya mercimek üretimi yılda ortalama olarak \%3.20 oranında artmıș ve dönem bașına nazaran dönem sonundaki artış ise \%408.82 olmuştur. Ekiliş alanlarında ise yıllık ortalama \%1.62 oranında artıș ve 1980 yılına nazaran 2016 yılındaki artış \%158.49 olmuştur (Çizelge 5). 2016 yılı dünya mercimek üretimi içerisinde \%51.2'lik payla Kanada ilk sırada yer almaktadır. Daha sonra sirasıyla Hindistan $\% 16.7$, Türkiye \%5.7, ABD \%4.0, Nepal \%4.0 ve Avustralya \%2.8'lik payla izlemektedir (FAO, 2018a). 1980-2016 döneminde ylllk ortalama mercimek üretimindeki artış Avustralya'da \%19.49, Kanada'da \%11,83, ABD'de \%4.99, Nepal'de \%4.63, Hindistan'da \%2.32 oranında gerçekleşmiştir. Türkiye'de ise 1980-2016 döneminde mercimek üretimi yılda ortalama \%1.32 oranında azalış göstermiş̦tir. Mercimek ekim alanlarına bakıldığında yıllık ortalama artış Avustralya'da \%18.65, Kanada'da \%9.96, ABD'de \%4.28, Nepal'de \%2.34, ve Hindistan'da \%1.49 olmuştur. Mercimek üretim miktarında olduğu gibi ekim alanında da Türkiye'de yıllık ortalama değişim \%2.87 oranında azalış göstermiştir. Üretim miktarı ve mercimek ekim alanlarında dünyada başat konumundaki ülkelerde artışlar söz konusu iken Türkiye'de azalış trendinin bulunması ilginç bir sonuç olarak karşımıza çıkmaktadır. Oysa TÜİK'in verilerine göre 2001 yılında kırmızı mercimekte yeterlilik oranımız
\%124.4 ve yeşil mercimekte \%87.7 iken 2016 yılında kırmızı mercimekte bu oran \%76.7'ye ve yeşil mercimekte de \%46.1'e düșmüștür. Türkiye 1980 yılındaki net ihracatçı konumundan özellikle kırmızı mercimekte net ithalatçı konumuna gelmiștir. Şekil 3'de görüleceği üzere mercimek ekim alanları özellikle 1980'li yılların sonundan itibaren azalmaya başlamış ve buna bağlı olarak üretimdeki azalma da 2008 yılına kadar devam etmiştir. Son yıllarda verimde bir miktar artış olmasına rağmen Türkiye'nin mercimek ekim alanı 2016 yılında ancak 1980 yılı seviyesine ulaşabilmiştir. Kırmızı mercimek üretimine bakıldığında 1988 yılında maksimum seviyeye ulaştıktan sonra azalmış ve azalış 2016 yılına kadar devam etmiştir. Nüfus artışına bağlı olarak da Türkiye kırmızı mercimekte kendi kendine yeterliliği kaybetmiștir.

\section{Baklagiller üretiminde işgücü verimliliği}

Çalışmada baklagiller üretiminde dünyada başat olan ülkelerin ve Türkiye'nin işgücü verimliliğinin karşılaştırılması yapılmıștır. Kuru fasulye üretiminde işgücü verimliliği ile ilgili bilgiler Çizelge 6'da verilmiştir. Çizelge'de görüleceği üzere dünya'da kuru fasulye üretiminde işgücü verimliliği 1991 yılına nazaran 2016 yılında 1.68 kat artış göstermiştir. Türkiye'de kuru fasulye üretimindeki işgücü verimliliği dünya ortalamasının üstünde (1.81 kat) olmuştur. Yani 1991 yılında $100 \mathrm{~kg}$ fasulye 
üreten bir çiftçi 2016 yllında $181 \mathrm{~kg}$ fasulye üretmektedir. Kuru fasulye üretiminde işgücü verimliliği en fazla artış gösteren ülke (17.05 kat) Myanmar olmuştur. Kuru fasulye üretimindeki işgücü verimliliğindeki yıllık ortalama değişim incelendiğinde dünyada ortalama olarak yılda \%2.65 oranında artış meydana gelirken, Türkiye'de \%2.14 artış gerçekleşmiştir.

Çizelge 5. Kırmızı mercimek üretim, ekim alanı ve verimindeki değişim (1980-2016)

\begin{tabular}{|c|c|c|c|c|c|c|}
\hline \multirow[b]{2}{*}{ Ülkeler } & \multicolumn{3}{|c|}{ Mercimek Üretimi } & \multicolumn{3}{|c|}{ Mercimek Ekiliş Alanı } \\
\hline & Regresyon Denklemi & $\begin{array}{l}\text { Yıllık Ortalama } \\
\text { Değișim(\%) }\end{array}$ & $\begin{array}{c}\text { Endeks } 2016 \\
(1980=100)\end{array}$ & Regresyon Denklemi & $\begin{array}{c}\text { Yıllık ortalama } \\
\text { Değișim(\%) }\end{array}$ & $\begin{array}{c}\text { Endeks } 2016 \\
(1980=100)\end{array}$ \\
\hline Dünya & $\mathrm{Y}=162112.1 .0319^{t}$ & 3.20 & 508.82 & $\mathrm{Y}=254790.1 .0162^{\mathrm{t}}$ & 1.62 & 258.49 \\
\hline Türkiye & $Y=64225 \cdot 0.9868^{t}$ & -1.32 & 187.17 & $\mathrm{Y}=785167.0 .9712^{\mathrm{t}}$ & -2.87 & 129.30 \\
\hline Kanada & $Y=49385 \cdot 1.11828^{t}$ & 11.83 & 12681.57 & $Y=56359.1 .0996^{t}$ & 9.96 & 4860.72 \\
\hline Hindistan & $Y=512681.1 .0232^{t}$ & 2.32 & 329.54 & $Y=946330.1 .0149^{t}$ & 1.49 & 182.38 \\
\hline $\mathrm{ABD}$ & $Y=42648.1 .0499^{t}$ & 4.99 & 260.74 & $Y=37509.1 .0428^{t}$ & 4.28 & 201.94 \\
\hline Nepal & $Y=47279.1 .0463^{t}$ & 4.63 & 516.41 & $\mathrm{Y}=98267.1 .0234^{\mathrm{t}}$ & 2.34 & 210.14 \\
\hline Avustralya & $Y=2909.1 .1949^{t}$ & 19.49 & 18163.80 & $Y=3516 \cdot 1.1865^{t}$ & 18.65 & 11247.20 \\
\hline
\end{tabular}

Kaynak: TÜIK 2012, TÜIK 2018a ve FAO 2018a'dan alınan veriler ile tarafımızca hesaplanmıștır.

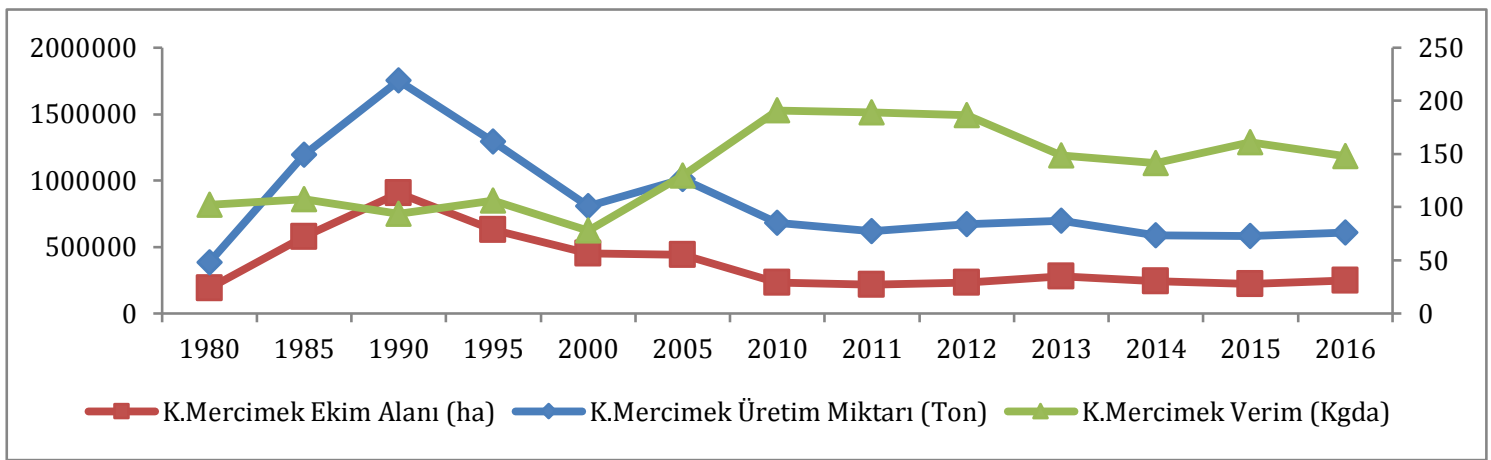

Şekil 3. Türkiye'de kırmızı mercimek üretim, ekiliş alanı ve verim değișmeleri

Yıllık ortalama artışın en yüksek olduğu ülke \%11.60 ile Myanmar olur iken en az artış \%0.74 ile Hindistan'da gerçekleşmiştir. Türkiye'de kuru fasulye üretimindeki işgücü verimliliği 1991-2016 döneminde artış göstermiş olmasına rağmen artışın önemli bir nedeninin tarımsal istihdamın azalış oranının, üretim artış oranından daha fazla olmasından kaynaklanmaktadır. Dolayısıyla Türkiye'de işgücü verimliliğinin artması tek başına üretim açısından yeterli bir faktör değildir. Tarımsal istihdamın değişmesinin yaratmış olduğu bu eksikliği giderebilmek amacıyla toplam nüfus itibarı ile kişi başına kuru fasulye üretiminin de incelenmesi gerekmektedir. Bu amaçla Türkiye'de ve dünyada kuru fasulye üretiminde başat olan bazı ülkelerin toplam nüfus itibarı ile kiși bașına kuru fasulye üretim miktarları hesaplanmış olup sonuçlar Çizelge 7' de verilmiştir. Türkiye'de 1991 yılında tarımda istihdam eden bir kişinin üretmiş olduğu kuru fasulye miktarı $24.33 \mathrm{~kg}$ iken 2016 yılında yaklaşık olarak 1.81 kat artarak 43.96 kg'a çıkmıştır. Aynı dönemde dünya ortalaması $18.42 \mathrm{~kg}$ dan 1.68 kat artarak 30.97 kg'a çıkmıştır. Diğer yandan 2016 yılı itibarı ile Türkiye'deki bir çiftçinin ürettiği kuru fasulyenin 11.26 katını ABD çiftçisi, 9.24 katını Myanmar çiftçisi, 6.40 katını Brezilya çiftçisi ve 1.56 katını Tanzanya çiftçisi üretmektedir. Diğer yandan Türkiye kuru fasulye verimi birim alana düșen verim bakımından dünya ortalamasının üzerinde iken verim artış oranları bakımından da dünya ortalamasının altında bulunmaktadır (Aydoğan ve ark., 2015). Çizelge7'de görüleceği üzere dünya'da kişi başına ortalama olarak 1991 yllında 3.35 kg, kuru fasulye üretimi gerçekleştirilir iken 2016 yılında 3.60 kg'a yükselmiştir. Türkiye'de ise 1991 yılında kişi başına kuru fasulye üretimi $3.90 \mathrm{~kg}$ iken, 2016 yllında 2.96 kg'a düşmüştür. Türkiye gibi ABD, Brezilya ve Hindistan'da da kişi başına üretilen kuru fasulye üretimi azalmıştır. Tarımda istihdam eden işgücünün verimliliğinin artmasına rağmen kişi başına kuru fasulye üretiminin her yıl azalması Türkiye'nin kuru fasulye bakımından kendi kendine yeterlilik düzeyinin azalmasına yol açmaktadır. Türkiye'de ortalama kişi başına kuru fasulye tüketiminin 3-4 kg (Şehirali, 1988) (TüİK, 2018c) civarında olduğu düşünülür ise 1991 yılında kendi kendine yeterli konumda olan Türkiye'nin gelecekte kuru fasulye bakımından dünyadaki başat ithalatçı 
konumda olacağı söylenebilir. Baklagiller içerisinde önemli bir payı olan nohut'un dünyada ve Türkiye'de işgücü verimliliği ile ilgili bilgiler Çizelge 8'de verilmiştir. Çizelge'de görüleceği üzere dünyada nohut üretimindeki işgücü verimliliği 1991 yılına nazaran 2016 yılında 1.68 kat artış gösterir iken, Türkiye'de 0.12 kat azalış söz konusu olmuştur. Aynı dönemde nohut üretiminde dünyada önde olan ülkelerden Myanmar'da 5.89, Avustralya'da 5.28, Etiyopya'da 1.65 ve Hindistan'da 1.39 kat artış söz konusu iken, Pakistan'da 0.5 kat azalış olmuştur.
İşgücü verimliliğindeki yıllık ortalama değişim incelendiğinde dünyada ortalama yıllık \%2.79 oranında artış söz konusu iken, Tükiye'de bu oran \%0.26 olarak gerçekleşmiştir. En fazla yıllık artış \%11.21 ile Myanmar'da olurken, Pakistan'daki değişim \%2.86 oranında azalmayla sonuçlanmıştır. Sonuçlar bize Türkiye'de nohut üretiminde işgücü verimliliğinin Türkiye'de oldukça düşük olduğunu ve bu düşüklüğün temel nedeninin de nohut üretim ve dolayısıyla ekiliş alanlarının azalmasından kaynaklandığını göstermektedir.

Çizelge 6. Kuru fasulye üretiminde işgücü verimliliği

\begin{tabular}{|c|c|c|c|c|c|c|c|}
\hline \multirow{2}{*}{ Yil } & Dünya & Türkiye & Myanmar & Hindistan & Brezilya & $\mathrm{ABD}$ & Tanzanya \\
\hline & \multicolumn{7}{|c|}{ Kuru fasulye üretim endeksi $(1991=100)$} \\
\hline 1991 & 100.00 & 100.00 & 100.00 & 100.00 & 100.00 & 100.00 & 100.00 \\
\hline 1995 & 98.79 & 105.14 & 213.87 & 97.48 & 107.34 & 90.89 & 122.26 \\
\hline 2000 & 99.08 & 107.48 & 365.23 & 80.67 & 111.35 & 78.61 & 149.97 \\
\hline 2005 & 107.07 & 98.13 & 618.07 & 74.55 & 110.09 & 78.71 & 173.95 \\
\hline 2010 & 136.90 & 99.42 & 1003.13 & 138.57 & 115.09 & 94.18 & 240.94 \\
\hline 2015 & 153.44 & 109.81 & 1398.45 & 120.71 & 112.58 & 89.21 & 333.81 \\
\hline 2016 & 148.94 & 109.81 & 1474.84 & 110.45 & 95.30 & 82.91 & 321.62 \\
\hline \multicolumn{8}{|c|}{ Tarımsal istihdam endeksi $(1991=100)$} \\
\hline 1991 & 100.00 & 100.00 & 100.00 & 100.00 & 100.00 & 100.00 & 100.00 \\
\hline 1995 & 101.91 & 95.46 & 106.57 & 105.91 & 110.79 & 105.77 & 114.26 \\
\hline 2000 & 104.12 & 81.98 & 113.92 & 112.87 & 95.29 & 76.49 & 128.63 \\
\hline 2005 & 102.55 & 58.24 & 108.77 & 121.72 & 110.34 & 67.52 & 143.85 \\
\hline 2010 & 94.86 & 60.73 & 96.42 & 114.05 & 92.93 & 67.96 & 165.36 \\
\hline 2015 & 89.14 & 61.88 & 86.34 & 105.20 & 62.63 & 74.77 & 183.34 \\
\hline 2016 & 88.56 & 60.79 & 86.51 & 104.84 & 60.65 & 75.84 & 187.97 \\
\hline \multicolumn{8}{|c|}{ Kuru fasulyede işgücü verimliliği } \\
\hline 1991 & 1.00 & 1.00 & 1.00 & 1.00 & 1.00 & 1.00 & 1.00 \\
\hline 1995 & 0.97 & 1.10 & 2.01 & 0.92 & 0.97 & 0.86 & 1.07 \\
\hline 2000 & 0.95 & 1.31 & 3.21 & 0.71 & 1.17 & 1.03 & 1.17 \\
\hline 2005 & 1.04 & 1.68 & 5.68 & 0.61 & 1.00 & 1.17 & 1.21 \\
\hline 2010 & 1.44 & 1.64 & 10.40 & 1.21 & 1.24 & 1.39 & 1.46 \\
\hline 2015 & 1.72 & 1.77 & 16.20 & 1.15 & 1.80 & 1.19 & 1.82 \\
\hline 2016 & 1.68 & 1.81 & 17.05 & 1.05 & 1.57 & 1.09 & 1.71 \\
\hline \multicolumn{8}{|c|}{ İșgücü verimliliğindeki yıllık ortalama değișim (\%) } \\
\hline & 2.65 & 2.14 & 11.6 & 0.74 & 2.65 & 1.95 & 2.26 \\
\hline
\end{tabular}

Kaynak: TÜİK 2012, TÜİK 2018a, FAO 2018a , FAO 2018c, ILO 2018'den alınan veriler ile tarafımızca hesaplanmıştır.

Çizelge 7. Türkiye'de ve bazı ülkelerde kişi başına kuru fasulye üretimi (kg)

\begin{tabular}{|c|c|c|c|c|c|c|c|}
\hline \multirow{2}{*}{ Yll } & Dünya & Türkiye & Myanmar & Hindistan & Brezilya & $\mathrm{ABD}$ & Tanzanya \\
\hline & & \multicolumn{6}{|c|}{ Tarımda istahdam eden kişi bașına kuru fasulye üretimi (kg) } \\
\hline 1991 & 18.42 & 24.33 & 23.84 & 17.21 & 179.21 & 453.54 & 40.49 \\
\hline 1995 & 17.85 & 26.80 & 47.85 & 15.84 & 173.63 & 389.70 & 43.33 \\
\hline 2000 & 17.53 & 31.90 & 76.44 & 12.30 & 209.41 & 466.11 & 47.21 \\
\hline 2005 & 19.23 & 41.00 & 135.49 & 10.54 & 178.80 & 528.71 & 48.97 \\
\hline 2010 & 26.58 & 39.83 & 248.07 & 20.91 & 221.94 & 628.53 & 59.00 \\
\hline 2015 & 31.70 & 43.18 & 386.19 & 19.75 & 322.12 & 541.10 & 73.72 \\
\hline 2016 & 30.97 & 43.96 & 406.48 & 18.13 & 281.61 & 495.87 & 69.29 \\
\hline \multicolumn{8}{|c|}{ Toplam nüfus itibarı ile kişi bașına kuru fasulye üretimi (kg) } \\
\hline 1991 & 3.35 & 3.90 & 8.54 & 3.97 & 18.06 & 6.05 & 13.68 \\
\hline 1995 & 3.11 & 3.85 & 17.41 & 3.58 & 18.15 & 5.23 & 14.69 \\
\hline 2000 & 2.92 & 3.64 & 27.88 & 2.70 & 17.44 & 4.27 & 15.80 \\
\hline 2005 & 2.96 & 3.09 & 44.86 & 2.30 & 16.17 & 4.08 & 15.89 \\
\hline 2010 & 3.56 & 2.94 & 70.38 & 3.97 & 16.05 & 4.66 & 18.82 \\
\hline 2015 & 3.76 & 3.00 & 93.91 & 3.25 & 15.00 & 4.26 & 22.31 \\
\hline 2016 & 3.60 & 2.96 & 98.14 & 2.94 & 12.60 & 3.93 & 20.84 \\
\hline
\end{tabular}

Kaynak: FAO 2018a, FAO 2018b, FAO 2018c, TÜIK 2012, TÜIK, 2018a,TÜIK 2018b, Worldbank 2018a ve ILO 2018'den alınan veriler ile tarafımızca hesaplanmıștır. 
Çizelge 8. Nohut Üretiminde İşgücü Verimliliği

\begin{tabular}{|c|c|c|c|c|c|c|c|}
\hline \multirow{2}{*}{ Yll } & Dünya & Türkiye & Avustralya & Hindistan & Myanmar & Pakistan & Etiyopya \\
\hline & \multicolumn{7}{|c|}{ Nohut üretim endeksi $(1991=100)$} \\
\hline 1991 & 100.00 & 100.00 & 100.00 & 100.00 & 100.00 & 100.00 & 100.00 \\
\hline 1995 & 112.98 & 85.38 & 129.32 & 120.15 & 83.24 & 105.18 & 82.59 \\
\hline 2000 & 99.04 & 64.09 & 73.02 & 95.55 & 106.92 & 106.31 & 109.20 \\
\hline 2005 & 104.46 & 70.18 & 60.95 & 102.11 & 237.07 & 163.52 & 143.90 \\
\hline 2010 & 133.84 & 62.06 & 219.53 & 139.65 & 418.40 & 105.74 & 214.14 \\
\hline 2015 & 135.92 & 53.80 & 250.34 & 136.85 & 520.49 & 71.41 & 345.56 \\
\hline 2016 & 148.94 & 53.22 & 394.21 & 145.97 & 509.46 & 97.38 & 294.61 \\
\hline \multicolumn{8}{|c|}{ Tarımsal istihdam endeksi $(1991=100)$} \\
\hline 1991 & 100.00 & 100.00 & 100.00 & 100.00 & 100.00 & 100.00 & 100.00 \\
\hline 1995 & 101.91 & 95.46 & 96.68 & 105.91 & 106.57 & 108.18 & 113.39 \\
\hline 2000 & 104.12 & 81.98 & 103.08 & 112.87 & 113.92 & 131.45 & 125.57 \\
\hline 2005 & 102.55 & 58.24 & 84.36 & 121.72 & 108.77 & 139.89 & 145.79 \\
\hline 2010 & 94.86 & 60.73 & 85.07 & 114.05 & 96.42 & 169.99 & 164.14 \\
\hline 2015 & 89.14 & 61.88 & 73.93 & 105.20 & 86.34 & 181.77 & 175.98 \\
\hline 2016 & 88.56 & 60.79 & 74.64 & 104.84 & 86.51 & 195.31 & 178.85 \\
\hline \multicolumn{8}{|c|}{ Nohut işgücü verimliliği } \\
\hline 1991 & 1.00 & 1.00 & 1.00 & 1.00 & 1.00 & 1.00 & 1.00 \\
\hline 1995 & 1.11 & 0.89 & 1.34 & 1.13 & 0.78 & 0.97 & 0.73 \\
\hline 2000 & 0.95 & 0.78 & 0.71 & 0.85 & 0.94 & 0.81 & 0.87 \\
\hline 2005 & 1.02 & 1.20 & 0.72 & 0.84 & 2.18 & 1.17 & 0.99 \\
\hline 2010 & 1.41 & 1.02 & 2.58 & 1.22 & 4.34 & 0.62 & 1.30 \\
\hline 2015 & 1.52 & 0.87 & 3.39 & 1.30 & 6.03 & 0.39 & 1.96 \\
\hline 2016 & 1.68 & 0.88 & 5.28 & 1.39 & 5.89 & 0.50 & 1.65 \\
\hline \multicolumn{8}{|c|}{ İşgücü verimliliğindeki yıllık ortalama değișim (\%) } \\
\hline & 2.79 & 0.26 & 7.95 & 2.2 & 11.21 & -2.86 & 5.08 \\
\hline
\end{tabular}

Kaynak: TÜİK 2012. TÜİK 2018a, FAO 2018a , FAO 2018c, ILO 2018’den alınan veriler ile tarafımızca hesaplanmıştır.

Çizelge 9. Türkiye'de ve bazı ülkelerde kişi başına nohut üretimi (kg)

\begin{tabular}{|c|c|c|c|c|c|c|c|}
\hline \multirow{2}{*}{ Yll } & Dünya & Türkiye & Hindistan & Avusturalya & Myanmar & Pakistan & Etiyopya \\
\hline & \multicolumn{7}{|c|}{ Tarımda istahdam eden kiși bașına nohut üretimi (kg) } \\
\hline 1991 & 8.30 & 97.23 & 26.12 & 525.73 & 7.44 & 37.31 & 8.29 \\
\hline 1995 & 9.20 & 86.96 & 29.64 & 703.21 & 5.81 & 36.27 & 6.04 \\
\hline 2000 & 7.90 & 76.02 & 22.12 & 372.41 & 6.98 & 30.17 & 7.21 \\
\hline 2005 & 8.45 & 117.14 & 21.92 & 379.82 & 16.22 & 43.61 & 8.19 \\
\hline 2010 & 11.71 & 99.35 & 31.99 & 1356.67 & 32.28 & 23.21 & 10.82 \\
\hline 2015 & 12.66 & 84.53 & 33.98 & 1780.13 & 44.85 & 14.66 & 16.28 \\
\hline \multirow[t]{2}{*}{2016} & 13.96 & 85.11 & 36.37 & 2776.49 & 43.81 & 18.60 & 13.66 \\
\hline & \multicolumn{7}{|c|}{ Toplam nüfus itibarı ile kiși bașına nohut üretimi (kg) } \\
\hline 1991 & 1.51 & 15.59 & 6.03 & 12.84 & 2.67 & 4.80 & 3.03 \\
\hline 1995 & 1.61 & 12.48 & 6.70 & 15.88 & 2.11 & 4.55 & 2.17 \\
\hline 2000 & 1.31 & 8.67 & 4.86 & 8.46 & 2.55 & 4.08 & 2.47 \\
\hline 2005 & 1.30 & 8.84 & 4.78 & 6.63 & 5.37 & 5.64 & 2.83 \\
\hline 2010 & 1.57 & 7.34 & 6.08 & 22.11 & 9.16 & 3.29 & 3.68 \\
\hline 2015 & 1.50 & 5.88 & 5.60 & 23.29 & 10.91 & 2.00 & 5.22 \\
\hline 2016 & 1.62 & 5.72 & 5.90 & 36.12 & 10.58 & 2.68 & 4.34 \\
\hline
\end{tabular}

Kaynak: FAO 2018a, FAO 2018b, FAO 2018c, TÜIK 2012, TÜIK, 2018a,TÜİK 2018b, Worldbank 2018a ve ILO 2018'den alınan veriler ile tarafımızca hesaplanmıştır.

Türkiye'de ve nohut üretiminde dünyada en büyük paya sahip olan ülkelerin nohut'un tarımda istihdam edilen kişi başına ve toplam nüfus itibarı ile kişi başına üretim miktarı ile ilgili veriler Çizelge 9' da verilmiştir. Çizelge 9'da görüleceği üzere dünya'da tarımda istihdam eden kişi başına 1991 yılında 8.30 kg nohut üretilir iken, 2016 yılında 13.96 kg'a yükselmiştir. Benzeri artışlar nohut üretiminde dünyada ilk sıralarda bulunan Hindistan, Avustralya, Myanmar ve Etiyopya'da da görülmektedir. Türkiye'de ise 1991 yılında $97.23 \mathrm{~kg}$ olan tarımda istihdam edilen kiși bașına nohut üretimi 2016 yılında 85.11 kg'a düşmüştür. Her ne kadar Türkiye'de tarımda istihdam edilen bir kişinin ürettiği nohut miktarı dünya ortalamasından ve birçok önemli nohut üreticisi ülkelerden daha yüksek olmasına rağmen, bu miktarın diğer ülkelerde her yll artmasına rağmen Türkiye'de azalması dikkat çekicidir. Tarımsal istihdamın da azaldığı göz önüne alındığında Türkiye'de tarımda istihdam başına nohut üretiminin azalmasının temel nedeni nohut ekim alanlarının azalmasından 
kaynaklanmaktadır. Dolayısıyla bu olgunun detaylı bir şekilde araştırılması önem arz etmektedir. Türkiye'de üreticilerin nohut üretiminden çekilmelerinin nedenleri olarak, ürün fiyatlarındaki düşüklük ve istikrarsızlık, Toprak Mahsulleri Ofisi'nin alımlardan çekilmesi, köyden kente göçün yoğun yaşandığı yörelerde işgücü azlı̆̆ ve işçi fiyatlarının yüksekliğinden kaynaklanan maliyet artışları gösterilmektedir (Karabak ve Cevher, 2002). Toplam nüfus dikkate alınarak kişi başına nohut üretim miktarı incelendiğinde benzeri sonuçlara ulaşılmaktadır. Türkiye'de üretilen nohut'un kişi başına düşen miktarı dünya ortalamasından çok daha fazla ve hatta önemli nohut üreticilerinden daha iyi olmasına rağmen her geçen yıl azalması son derece önemlidir. Türkiye'de kişi başına nohut tüketiminin ortalama olarak $5.5-6.0 \mathrm{~kg}$ olduğu dikkate alındığında (TÜIK, 2018c), 2016 yılında üretilen $5.72 \mathrm{~kg}$ nohut ile Türkiye'nin kendi kendine yeterliliğinin kaybolduğu söylenebilir. Nihayet TÜIK kaynaklarına göre Türkiye'de nohutta yeterlilik oranı 2000 yılında \%115 iken 2016 yılında \%92'ye düşmüştür. Türkiye'de baklagiller üretimindeki azalmaya engel olmak amaciyla 2008 ylında başlatılan destekleme ödemesi, üreticileri tekrar üretime döndürmüștür (TZOB, 2010). Bunun sonucunda 2007 yllında 505000 ton civarında olan nohut üretimi 2009 yılında 562524 ton'a çıkmış ancak takip eden yllarda bu düzeyini koruyamamıştır. Türkiye'de baklagiller dış ticaretine en fazla konu olan mercimek işgücü verimliliği itibarı ile incelendiğinde durum diğer baklagillere nazaran daha kötü durumdadır. Çizelge 10 'da mercimek üretiminde dünyada ilk beșe giren ülkeler ile Türkiye'de işgücü verimliliği ve değişim oranları tarafımızca hesaplanarak verilmiştir. Çizelge'de görüleceği üzere dünya'da mercimek üretimindeki işgücü verimliliği 1991 yılından itibaren kademeli olarak artarak 2016 yılında 2.68 olmuştur. Dünya'da mercimek üretimindeki işgücü verimliliği yılda ortalama olarak \%3.64 oranında artış göstermiștir. Mercimek üretiminde işgücü verimliliği Avustralya'da 243.34 kat, Kanada'da 15.05 kat, ABD'de 4.42 kat, Nepal'da 2.21 kat ve Hindistan'da 1.18 kat artmış olmasına rağmen Türkiye'de azalış söz konusu olmuştur (0.94). Diğer yandan yıllık ortalama değişim itibarı ile bütün ülkelerde mercimek üretimindeki işgücü verimliliği artarken, Türkiye'de yılda ortalama olarak \%0.27 oranında azalış olmuştur, Dünya'da mercimek üretimindeki işgücü verimliliğinin artmasına rağmen Türkiye'de azalması kişi başına düşen mercimek üretim miktarını da etkileyecektir. Dünyanın mercimek üretiminde başat konumunda olan ülkeler ve Türkiye'de tarımda istihdam edilen nüfus başına ve toplam nüfus itibarı ile kişi başına mercimek üretimi verileri Çizelge 11 'de verilmiştir.

Çizelge 10. Mercimek üretiminde işgücü verimliliği

\begin{tabular}{|c|c|c|c|c|c|c|c|}
\hline \multirow{2}{*}{ Yll } & Dünya & Türkiye & Kanada & Hindistan & ABD & Nepal & Avustralya \\
\hline & \multicolumn{7}{|c|}{ Mercimek üretim endeksi (1991=100) } \\
\hline 1991 & 100.00 & 100.00 & 100.00 & 100.00 & 100.00 & 100.00 & 100.00 \\
\hline 1995 & 107.69 & 103.91 & 126.02 & 92.06 & 132.46 & 136.64 & 1700.00 \\
\hline 2000 & 127.28 & 55.16 & 266.66 & 126.72 & 180.40 & 188.09 & 16300.00 \\
\hline 2005 & 147.13 & 89.06 & 339.64 & 116.77 & 312.50 & 220.10 & 5230.10 \\
\hline 2010 & 177.75 & 69.91 & 584.83 & 121.17 & 515.59 & 207.83 & 14000.00 \\
\hline 2015 & 206.35 & 56.25 & 741.10 & 121.56 & 314.23 & 311.55 & 23050.00 \\
\hline 2016 & 237.62 & 57.03 & 943.35 & 123.98 & 334.90 & 346.54 & 18163.80 \\
\hline \multicolumn{8}{|c|}{ Tarımsal istihdam endeksi $(1991=100)$} \\
\hline 1991 & 100.00 & 100.00 & 100.00 & 100.00 & 100.00 & 100.00 & 100.00 \\
\hline 1995 & 101.91 & 95.46 & 96.18 & 105.91 & 105.77 & 111.80 & 96.68 \\
\hline 2000 & 104.12 & 81.98 & 86.28 & 112.87 & 76.49 & 114.12 & 103.08 \\
\hline 2005 & 102.55 & 58.24 & 77.95 & 121.72 & 67.52 & 130.69 & 84.36 \\
\hline 2010 & 94.86 & 60.73 & 70.14 & 114.05 & 67.96 & 138.86 & 85.07 \\
\hline 2015 & 89.14 & 61.88 & 64.41 & 105.20 & 74.77 & 152.65 & 73.93 \\
\hline 2016 & 88.56 & 60.79 & 62.67 & 104.84 & 75.84 & 156.64 & 74.64 \\
\hline \multicolumn{8}{|c|}{ Mercimek ișgücü verimliliği } \\
\hline 1991 & 1.00 & 1.00 & 1.00 & 1.00 & 1.00 & 1.00 & 1.00 \\
\hline 1995 & 1.06 & 1.09 & 1.31 & 0.87 & 1.25 & 1.22 & 17.58 \\
\hline 2000 & 1.22 & 0.67 & 3.09 & 1.12 & 2.36 & 1.65 & 158.13 \\
\hline 2005 & 1.43 & 1.53 & 4.36 & 0.96 & 4.63 & 1.68 & 62.00 \\
\hline 2010 & 1.87 & 1.15 & 8.34 & 1.06 & 7.59 & 1.50 & 164.57 \\
\hline 2015 & 2.31 & 0.91 & 11.51 & 1.16 & 4.20 & 2.04 & 311.77 \\
\hline 2016 & 2.68 & 0.94 & 15.05 & 1.18 & 4.42 & 2.21 & 243.34 \\
\hline \multicolumn{8}{|c|}{ İșgücü verimliliğindeki yıllık ortalama değișim (\%) } \\
\hline & 3.64 & -0.27 & 11.17 & 1.04 & 7.54 & 2.39 & 18.98 \\
\hline
\end{tabular}

Kaynak: TÜİK 2012, TÜİK 2018a, FAO 2018a , FAO 2018c, ILO 2018'den alınan veriler ile tarafımızca hesaplanmıștır. 
Çizelge 11. Kişi başına mercimek üretimi

\begin{tabular}{|c|c|c|c|c|c|c|c|}
\hline \multirow{2}{*}{ Yll } & Dünya & Türkiye & Kanada & Hindistan & ABD & Nepal & Avustralya \\
\hline & \multicolumn{7}{|c|}{ Tarımda istahdam eden kişi bașına mercimek üretimi (kg) } \\
\hline 1991 & 2.72 & 72.78 & 595.14 & 4.15 & 22.55 & 9.78 & 2.37 \\
\hline 1995 & 2.87 & 79.21 & 779.78 & 3.61 & 28.24 & 11.95 & 41.67 \\
\hline 2000 & 3.32 & 48.97 & 1839.24 & 4.66 & 53.19 & 16.12 & 374.71 \\
\hline 2005 & 3.90 & 111.28 & 2593.10 & 3.98 & 104.39 & 16.47 & 146.91 \\
\hline 2010 & 5.09 & 83.77 & 4962.38 & 4.41 & 171.10 & 14.64 & 389.97 \\
\hline 2015 & 6.29 & 66.15 & 6847.71 & 4.80 & 94.78 & 19.96 & 738.78 \\
\hline \multirow[t]{2}{*}{2016} & 7.29 & 68.28 & 8957.89 & 4.91 & 99.59 & 21.64 & 576.63 \\
\hline & \multicolumn{7}{|c|}{ Toplam nüfus itibarı ile kiși bașına mercimek üretimi (kg) } \\
\hline 1991 & 0.49 & 11.67 & 12.17 & 0.96 & 0.30 & 3.79 & 0.06 \\
\hline 1995 & 0.50 & 11.37 & 14.72 & 0.82 & 0.38 & 4.66 & 0.94 \\
\hline 2000 & 0.55 & 5.58 & 29.71 & 1.02 & 0.49 & 5.79 & 8.51 \\
\hline 2005 & 0.60 & 8.39 & 36.03 & 0.87 & 0.81 & 6.27 & 2.56 \\
\hline 2010 & 0.68 & 6.19 & 58.96 & 0.84 & 1.27 & 5.62 & 6.35 \\
\hline 2015 & 0.75 & 4.60 & 70.90 & 0.79 & 0.75 & 7.94 & 9.66 \\
\hline 2016 & 0.85 & 4.59 & 89.17 & 0.80 & 0.79 & 8.73 & 7.50 \\
\hline
\end{tabular}

Kaynak: FAO 2018a, FAO 2018b, FAO 2018c, TÜİK 2012, TÜİK, 2018a,TÜİK 2018b, Worldbank 2018 , ILO 2018 verilerİ ile hesaplanmıştır.

Çizelgede görüleceği üzere dünyada tarımda istihdam edilen her bireyin ürettiği mercimek miktarı 1991-2016 döneminde her yıl artış göstermiş olup 2016 yılında 7.29 kg'a ulaşmıştır. Türkiye dünya ortalamasının çok üzerinde olup tarımda istihdam eden bir kişinin üretmiş olduğu mercimek miktarı 2016 yılı itibarı ile $68.28 \mathrm{~kg}$ dır. Bu konuda Türkiye'den çok daha iyi konumda olan ülkeler söz konusu olup Kanada'da 8957.89 kg, Avustralya'da $576.63 \mathrm{~kg}$ ve ABD'de $99.59 \mathrm{~kg}$ mercimek üretimi gerçekleştirilmiștir. Hindistan ve Nepal'de tarımda istihdam edilen kişi başına mercimek üretimi Türkiye ortalamasının altındadır. Türkiye'de dikkat çeken husus tarımda istihdam edilen kişi başına mercimek üretimi dünyada ve diğer ülkelerde artarken Türkiye'de azalma trendinde olmasıdır. Bu olgu Türk çiftçisinin mercimek üretiminden çekildiğini göstermektedir. Toplam nüfus itibarı ile kişi başına düşen mercimek üretimi incelendiğinde 2016 yılında dünya ortalaması $0.85 \mathrm{~kg}$ iken, Kanada'da $89.17 \mathrm{~kg}$, Nepal'de 8.73 kg, Avstralya'da 7.50 kg, Türkiye'de $4.59 \mathrm{~kg}$ mercimek üretimi gerçekleştirilirken, Hindistan ve ABD dünya ortalamasının altında mercimek üretimi gerçekleştirmiştir. Burada da dikkati çeken husus, Türkiye ve Hindistan dışındaki tüm ülkelerde kişi başına mercimek üretimi 19912016 döneminde artarken Türkiye ve Hindistanda azalmıştır. Türkiye'de kişi başına mercimek tüketiminin 5-5.5 kg olduğu düşünüldüğünde Türkiye'de mercimek üretiminin yetersiz olduğu söylenebilir. TÜİK verilerine göre 2006 yılına kadar mercimekte kendine yeterli olan Türkiye'nin (\%185.4) 2008 yllından itibaren kendi kendine yeterli olma özelliği kaybolmuş ve yeterlilik oranı 2016 yılında \%76.7'ye düşmüștür (TÜİK, 2018c).

\section{Sonuç ve Öneriler}

FAO'nun 2016 yılı verilerine göre dünyada yaklaşık olarak 48 milyon ha alanda 48 milyon ton kuru faslye, nohut ve mercimek üretimi gerçekleştirilmektedir. Baklagiller içerisinde ilk sırayı kuru fasulye alırken bunu sırasıyla nohut ve mercimek izlemektedir. Türkiye üretim itibarı ile kuru fasulye üretiminde 22. sırada, nohut üretiminde beşinci sırada ve mercimek üretiminde de üçüncü sırada yer almaktadır. Ekiliş alanları itibarı ile Türkiye dünyada mercimekte üçüncü sırada, nohutta yedinci sirada ve kuru fasulyede 39. sirada bulunmaktadır. Gerek insan beslenmesindeki önemi ve gerekse münavebeli ekimde son derece öneme sahip olan baklagillerin 1980-2016 döneminde Türkiye'de ve bașat ülkelerde üretiminde nasıl bir değişimin olduğu, 1991-2016 döneminde baklagiller üretiminde işgücü verimliliğinin nasıl değiştiği ve kişi başına baklagiller üretimindeki değişimin nasıl değiştiğinin karşılaştırılmalı olarak incelenmesini amaçlayan bu çalışmada elde edilen sonuçlar şöyle özetlenebilir. Türkiye'de 1980-2016 döneminde kuru fasulye üretiminde yıllık ortalama artış dünya ortalamasının altında olup, 1990'lı yılların ortasında yakaladığı üretim miktarına 2016 yılında dahi ulaşamamıştır. Aynı dönemde kuru fasulye ekim alanı birçok ülkenin aksine azalma eğilimi içinde olup, çiftçilerin kuru fasulye üretiminden çekildiğini göstermektedir. Diğer yandan kuru fasulye'de kendi kendine yeterliliğini kaybedip net ithalatçı konumuna gelmiștir. Nohut üretim ve ekiliş alanları değerlendirildiğinde benzeri sonuçlara ulaşılmaktadır. Dünyadaki ortalama nohut üretim ve ekiliş oranlarındaki yıllık artış Türkiye'den daha yüksek bulunmuştur. Mercimek üretim ve ekiliş 
alanlarındaki durum daha kötü olup dünyada ve başat konumunda olan ülkelerde mercimek ekiliş ve üretim alanlarında her yıl artışlar yaşanmasına rağmen Türkiye'de azalışlar söz konusu olup bu alandaki yeterlilik büyük ölçüde kaybedilmiştir. 1991-2016 döneminde baklagillerden kuru fasulye'de işgücü verimliliği dünyada yıllık ortalama olarak \%2.65 artış göstermiștir. Türkiye'de ise kuru fasulyede işgücü verimliliği yılda ortalama \% 2,14 artmıştır. Ancak dünyada tarımsal istihdamda Türkiye'den daha yavaş bir azalış söz konusu olduğundan Türkiye'deki işgücü verimliliği artışının önemli bir kısmının tarımdaki istihdam azalıșından kaynaklandığı ve üreticilerin bu alandan çekildiklerini göstermektedir. Benzeri durum diğer baklagillerde de görülmektedir. Nohut üretiminde dünyadaki ortalama yıllık \%2.79 artış söz konusu iken Türkiye'deki artış \%0.26 olmuştur. Mercimekte ise sonuç daha kötümser olup, dünya' da ortalama mercimekteki işgücü verimliliği \%3.64 artış göstermesine rağmen Türkiye'de $\% 0.27$ oranında azalış söz konusu olmuştur. Bütün bu sonuçlar bize Türkiye'de baklagiller üretiminde her yıl azalışların olduğu, üreticilerin ekim alanlarını daraltarak bu alandan çekildiğini bunun sonucu olarak ülkenin baklagiller yönünden kendi kendine yeterliliğini kaybettiği göstermektedir. Bunların telafi edilmesi ve Türkiye'nin baklagiller üretiminde ve yeterliliğinde eski günlere dönülebilmesi için yapılması gerekenler şöyle özetlenebilir.

-Verimliliğin arttırılması amacıyla sertifikalı tohumluğa üreticilerin yönlendirilmesi.

-Girdi maliyetlerin belirlenmesinde gerçekçi politikaların izlenmesi.

-Baklagiller alımında kesinti olmaksızın TMO tarafından pazarlama politikasının oluşturulması.

-Baklagiller fiyatlarının ürünün piyasadaki bol veya kıt olmasına göre değil maliyetlerin esas alındı̆̆ı bir sistem içerisinde gerçekleştirilmesi sağlanmalıdır.

-Baklagiller ithalatında yurtiçindeki üreticileri mağdur etmeyecek bir sistem oluşturulmalıdır.

Baklagiller üretiminde geleneksel yöntemler yerine pazara yönelik üretimi teşvik edici unsurlar devreye konulmalı ve toprak toplulaştırması yapılmalıdır.

\section{Kaynaklar}

Akal, Z., 2005. İşletmelerde Performans Ölçüm ve Denetimi-Çok Yönlü Performans Göstergeleri”, MPM Yayın No:473, Ankara.
Aydoğan, M., Demiryürek, K., Abacı, N.İ., 2015. Türkiye'de Kuru Fasulye Üretiminin Mevcut Durumu, Türk TarımGida ve Teknoloji Dergisi, 3(12):962-968.

Bolat, M., Ünüvar, İ., Dellal, İ., 2017. Türkiye'de Yemeklik Baklagillerin Gelecek Eğilimlerinin Belirlenmesi, Tarım Ekonomisi Araştırmaları Dergisi, 3(2):7-18.

Çiftçi, C.Y., 2004. Dünya'da ve Türkiye'de Yemeklik Baklagiller Tarımı, TMMOB Ziraat Mühendisleri Odası Teknik yayınlar Dizisi, No:5, s.10

FAO, 2018a. Crops Productions, http://www.fao.org /faostat, (Erișim Tarihi 26 Nisan 2018)

FAO, 2018b. Annual Population, http://www.fao.org/ faostat, (Erişim Tarihi 25 Mayıs 2018)

FAO, 2018c. Employment İndicators, http://www.fao.org/ faostat (Erişim Tarihi 28 mayıs 2018).

ILO, 2018. Key Indicators of the Labour Market (KILM) http://www.ilo.org/ (Erişim Tarihi 10 Mart,2018).

Karabak, S., Cevher, C., 2002. Orta Anadolu Bölgesinde Nohut ve mercimek Tarımını Sinırlandıran SosyaEkonomik Faktörlerin Tespiti, Tarla Bitkileri Merkez Araştırma Enstitüsü Dergisi, 11(2): 99-119.

KB, 2014. Kalkınma Bakanlığı Onuncu Kalkınma Planı Bitkisel Üretim Özel ihtisas Komisyonu Raporu.

OECD, 2018. Agricultural Policy Monitoring and Evaluation, OECD, Pablishing, Paris.

Ramsay, M.R., 2008. İşletme Verimliliği Ölçümü Ve Uluslararası İşgücü Verimliliği El kitabı, Ankara

Suiçmez, H., 2016. Dünya'da ve Türkiye'de Verimlilikte Son Durum, Kalkınmada Anahtar Verimlilik, Bilim Sanayi ve Teknoloji Bakanlığg Verimlilik Genel Müdürlüğü.

Şehirali S., 1988. Yemeklik Dane Baklagiller. A.Ü.Z.F. Yayınları: 1089, Ankara. 435.

TÜIK, 2018a. Bitkisel Üretim İstatistikleri, http://www.tuik.gov.tr (Erişim Tarihi 20 Mayıs, 2018)

TÜİ, 2018b. Adrese Dayalı Nüfus Kayıt Sistemi (ADNKS), http://www.tuik.gov.tr ( Erişim Tarihi 20 Mayıs, 2018)

TÜIK, 2018c. Bitkisel Ürün Denge Tablolarl, http:/www.tuik.gov.tr/ (Erişim Tarihi 30 Nisan 2018)

TZOB, 2010. Türkiye Ziraat Odaları Birliği, Zirai iktisadi Raporlar https://www.tzob.org.tr/zirai-iktisadiraporlar (Erişim Tarihi 19 Haziran 2018).

WERY and GRICNAC, 1983. The Leguminosae Family. II. Syst 1, p1-8. That Fix Nitrogen. Technical Handbook on Symbiotic Nitrogen Fixation.Legume, Rome.

Worldbank, 2018a. World Development İndicators, https://data.worldbank.org/indicator/SP. POP. TOTL (Erişim Tarihi 20 mayıs 2018) 